\title{
EL GRAJO DE ESOPO: LUCIANO Y LA TRADICIÓN YÁMBICA
}

\author{
Pilar Gómez ${ }^{\star}$ \\ Universitat de Barcelona
}

RESUMO: As obras de Luciano de Samósata respondem a um complexo mecanismo de criação literária, em que o uso paradoxal dos gêneros literários é prática habitual. N'O crítico falaz ou sobre o termo nefasto [ $=$ Pseudologista], o samosatense escreve um virulento ataque contra um indivíduo que se dedica a fazer declamações públicas, mas que exerce mal o ofício de sofista e, por causa disso, merece ser o destinatário de uma implacável invectiva. Para que não reste dúvida alguma de qual é a tradição literária, poética neste caso, que inspira a sátira de Luciano, nos primeiros capítulos da obra aparecem citados os mais ilustres jambógrafos gregos - Arquíloco, Hipônax ou Semônides - e, com eles, também é mencionado Esopo. O objetivo deste trabalho é analisar como Luciano, que conhece bem o corpus esópico e recorre a ele em diversas ocasiões, quando associa, em Pseudologista, Esopo e a poesia jâmbica, não só mostra mais uma vez com que intenção pode servir-se das fábulas e adaptá-las de forma variada nas suas obras, mas também, como crítico literário, ensinanos sobre os conteúdos de burla e ataque verbal próprios da tradição em que este gênero funda as suas raízes.

PALAVRAS-CHAVE: Luciano; Esopo; poesia jâmbica; fábula; invectiva.

Pero resultaba que el discurso de aquel sofista, como el grajo de Esopo, era una especie de remiendo de variadas plumas ajenas. ${ }^{1}$

^pgomez@ub.edu

${ }^{1}$ Lucianus, Pseudol. 5. 
stas palabras se encuentran en uno de los capítulos iniciales de la obra Un crítico falaz o sobre el término "nefasto" [ = Pseudologista ], que Luciano escribe como un discurso pronunciado por un sofista prestigioso contra un orador inepto, después que éste no sólo le había plagiado una pieza de su repertorio durante una declamación a la que él mismo asistía, sino porque también se atrevió a acusarle de usar de forma incorrecta algunas palabras. Por ambas faltas el individuo que ejerce mal su oficio de sofista merece ser el destinatario de una implacable invectiva. ${ }^{2}$

En la tradición griega, desde bien temprano, "fábula" y "Esopo" son términos difícilmente separables, pues también ese género - antiguo y de larga pervivencia - anduvo a la búsqueda de un inventor, de un

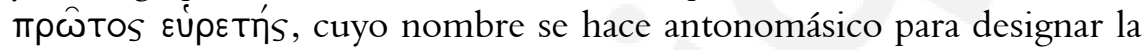
fábula misma, de modo que cualquier relato identificable como fábula es susceptible de ser presentado como dicho por Esopo en una determinada circunstancia. Es lo que hace aquí Luciano, quien no cuenta ningún apólogo animal, sino que se limita a formular una simple comparación inserida en el discurso del sofista, y que le sirve para explicar sucintamente el vacuo proceder del necio orador.

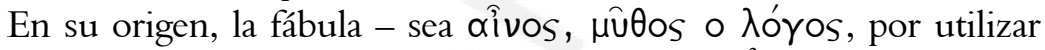
solo tres de los vocablos griegos con que se la designa $-{ }^{3}$ no fue un género autónomo, sino un segmento narrativo engarzado en otros géneros, como ilustra ya Hesíodo, cuando mediante la historia (aîvos) del halcon y el ruiseñor exhorta y aconseja a Perses sobre la insensatez de creerse superior. ${ }^{4}$ Hesíodo es, pues, punto de partida y modelo de uno de los usos primordiales de la fábula, al incorporar en sus versos como exemplum un relato protagonizado por animales, que él mismo inventa o adopta y adecúa a sus hexámetros, quizás a partir de algún relato o motivo tradicional.

De Hesíodo a Luciano el recorrido es largo y numerosas las vicisitudes y formas que adopta la fábula en la tradición literaria griega. No se trata ahora de mencionar siquiera los jalones principales de ese camino por ser sobradamente conocidos, pero sí de recordar algunos aspectos significativos y puntos importantes para mejor encuadrar este trabajo de hoy.

En el período postclásico, la fábula, al igual que ocurre con los refranes ${ }^{5}$ y, en general, con las máximas y dichos de carácter gnómico,

${ }^{2}$ Cf. Mestre, op. cit., 2012, p. 267-271.

${ }^{3}$ Cf. Van Dijk, op. cit., 1997, p. 90-97.

${ }^{4}$ Hes., Op. 202-218.

${ }^{5}$ Cf. Montanari, op. cit., p. 257-259. 
deviene género antológico, al ser copiados y recopiados, una y otra vez, como literatura, esos apólogos animales, que así circulan libremente a través de los géneros literarios; aparecen como literatura elevada o como textos escolares; mantienen una forma prosificada o son vertidos en formas métricas. ${ }^{6}$ No es casual que las primeras colecciones de gnomologías daten de época helenística, pues, por una parte, recogen el gusto por la antología de tradición peripatética y, por otra, por su uso escolar y contenido dan respuesta también a temas de carácter ético. En la constitución de estas antologías, la autoridad de una figura "histórica", que es presentada haciendo o diciendo algo éticamente significativo, juega un papel decisivo. Como sabemos por Diógenes Laercio, la primera recopilación en prosa de fábulas, unida ya a la autoridad de Esopo, fue hecha por Demetrio de Falero.

Tomando esta compilación como punto de referencia, Adrados, al estudiar en su conjunto la historia de la fábula, esbozó su evolución y desarrollo en época helenística e imperial en tres etapas - el siglo III a.C., el siglo I a.C. y el siglo I d.C. -, cada una de las cuales se identificaría, respectivamente, con una producción de fábulas en verso, con una prosificación de las colecciones métricas y con la aparición de colecciones literarias. ${ }^{8}$ No obstante, la presencia y el predominio de una u otra forma están también determinados por el uso específico de la fábula en cada momento y, por lo tanto, no deben ser solamente criterios formales los que sirvan para intentar fijar el camino seguido por la fábula en este dilatado período, sino que deben tenerse en cuenta además su contenido y su función.

Desde esta perspectiva, en el período helenístico e imperial la fábula se presenta con dos grandes usos principales, que no son excluyentes entre sí: la fábula cínica y la fábula moralizante-didácticaescolar. Estos descriptores resultan operativos en términos generales, pero, paralelamente al desarrollo de las colecciones, la fábula siguió siendo usada por poetas y por prosistas; y además se escribieron colecciones literarias, personales, como las de Fedro y Babrio, ${ }^{9}$ cada una de ellas con una intención y un estilo peculiar. Fedro desarrolló

\footnotetext{
${ }^{6}$ Cf. Morgan, op. cit., 1998, p. 126-151.

${ }^{7}$ D.L. I 80-81. Sobre el origen peripatético de la documentación de Diógenes Laercio relativa a los sucesores de Aristóteles, véase Moraux, op. cit., p. 245-294.

${ }^{8}$ Cf. Rodríguez Adrados, op. cit., 1970; op. cit., 1979a, p. 509-699.

${ }^{9}$ Cf. Rodríguez Adrados, op. cit., 1978, p. 26.
} 
más el aspecto instructivo de la fábula mientras que Babrio se interesó más por el aspecto literario, pero ambos coinciden en el uso escolar de la fábula, especialmente en las escuelas de retórica. ${ }^{10}$ Ello significa, pues, que se continuaron las antiguas colecciones - fueran poéticas o prosificadas -, dando lugar a nuevas colecciones de fábulas anónimas, pero con influjos recíprocos entre esas colecciones y la tradición indirecta.

En una época de retórica aplicada - para decirlo con terminología de Reardon -, Luciano se revela como un escritor mucho más hábil y ágil que sus contemporáneos en el uso simultáneo tanto de la literatura del pasado como de los métodos escolares del presente, pero no cabe duda de que tanto el samosatense como sus coetáneos han recibido una misma formación. Las escuelas de retórica dotan a sus alumnos, futuros sofistas y hombres de letras en general - esos que se autoidentifican

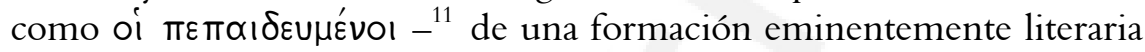
$\mathrm{y}$, de forma recíproca, esa formación retórica, basada en los modelos del clasicismo ateniense, marca la producción de los escritores de ese período, ${ }^{12}$ que se ha convenido en llamar Segunda Sofística, ${ }^{13}$ a partir de la denominación de Filóstrato. ${ }^{14}$

Si los sofistas despertaban con sus declamaciones gran expectación y entusiasmo entre el público - como explica Filóstrato ${ }^{15}$ y confirma también Luciano - ${ }^{16}$ era no sólo por el espectáculo que ofrecían, sino también porque unos y otros habían frecuentado las escuelas de retórica, que suministraban tanto a los sofistas como a su público un amplio repertorio de tópicos tratados en multitud de ocasiones por medio de

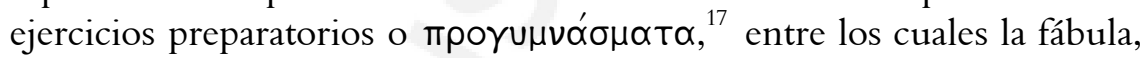
el relato, la $\chi \rho \varepsilon \hat{\imath} \alpha$, la sentencia y la confirmacion, constituían el catálogo de los más sencillos. ${ }^{18}$

${ }^{10}$ Cf. Morgan, op. cit., 2007, p. 377-394.

${ }^{11}$ Cf. Anderson, op. cit., 1989.

${ }^{12}$ Cf. Bompaire, op. cit., p. 294-301, sobre la influencia de determinados ejercicios preparatorios en la obra de Luciano; y Reardon, op. cit., p. 99-154 para la vinculación entre retórica y literatura.

${ }^{13}$ Cf. Anderson, op. cit., 1993, p. 47-68.

${ }^{14}$ Philostr. VS 481.

${ }^{15}$ Cf. Mestre y Gómez, op. cit., 1998, p. 353-364.

${ }^{16}$ Lucianus Rh. Pr. 18-21; Gómez, op. cit., 2005, p. 334-337.

${ }^{17}$ Cf. Kennedy, op. cit., p. 201-229; Mestre, op. cit., 2007, p. 524.

${ }^{18}$ Cf. Webb, op. cit., p. 289-316; Cribiore, op. cit., p. 221-225. 


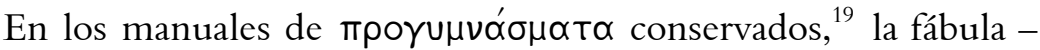
$\mu \hat{u} \theta 0$ s es el nombre que todos ellos le dan - encabeza siempre el elenco de ejercicios. En el atribuido a Hermógenes ${ }^{20}$ se destaca la utilidad de la fábula por su valor educativo -"modela a los jóvenes cuando aún son

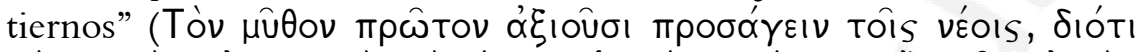

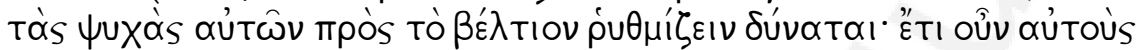

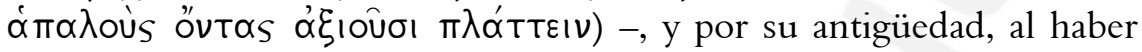
sido utilizada ya por Hesíodo y Arquíloco; y las fábulas son denominadas sibaríticas, carias, frigias o libias, según sea la procedencia de sus inventores, aunque todos esos tipos de $\mu \mathrm{u} \theta 0 \mathrm{I}$ son "esópicos", porque Esopo "utilizaba las fábulas para sus conversaciones habituales" (та丿) Ex

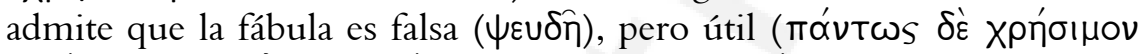

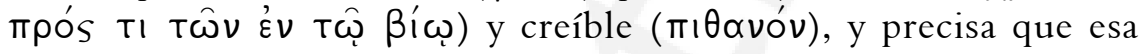
credibilidad, persuasiva, surge porque a los personajes de las fábulas se les asignan las características que les son propias, y lo ilustra con ejemplos: "Alguien compite por la belleza, a ése que se le presente como un pavo real; ${ }^{22}$ hay que atribuir a alguien cierta sabiduría, entonces que sea presentado como una zorra; si imitan las acciones de los hombres, entonces que sean propuestos los monos." 23

En cuanto a la puesta en práctica, Hermógenes indica que las fábulas se pueden contar sin adornos como una mera narración ( $\psi 1 \lambda$ òv

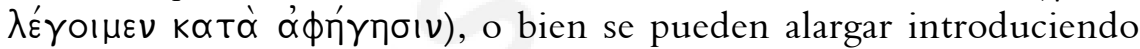

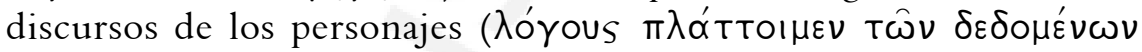

\footnotetext{
${ }^{19}$ Se trata de los atribuidos a Hermógenes, Teón, Aftonio y Nicolao, que presentan numerosas coincidencias entre ellos, aunque cada autor imprime su sello particular: Teón trata con sumo detalle cada ejercicio preparatorio y ofrece abundantes ejemplos extraídos de obras antiguas, prueba inequívoca de la estrecha relación entre retórica y literatura, mientras que el manual de Aftonio fue quizá el más influyente y novedoso, al incluir ejemplos acabados de cada ejercicio.

${ }^{20}$ Philostr. VS 577-578.

${ }^{21}$ Teón, por su parte, justifica la preeminencia de Esopo, afirmando que éste se sirvió más y con mayor habilidad de las fábulas, mientras que Aftonio explica la denominación de esópicas porque "fue Esopo quien mejor compuso fábulas". El

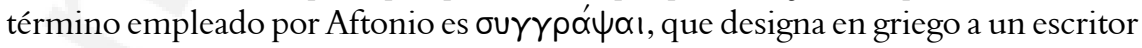
de prosa, habitualmente a un historiador.
}

${ }^{22}$ Aesop. 219, El pavo real y el grajo.

${ }^{23}$ Aesop. 203, El mono y los pescadores. 


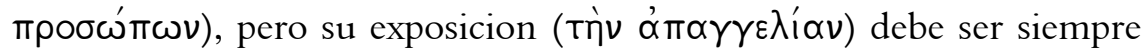
sencilla, ajena a los períodos y "cercana a la dulzura" ( $\gamma \lambda$ unútntos દ’ $\gamma$ ús) - tal vez por ello, Babrio se propone restar a sus versos el amargo sabor del yambo:
$\mu$ ứ

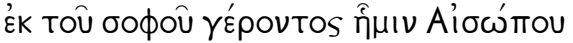

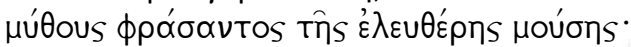

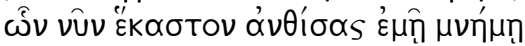

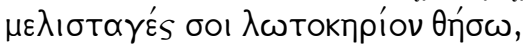

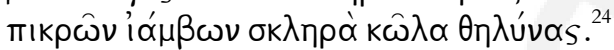

El testimonio de los tratados de retórica constata el interés y el gusto helenísticos por la codificación de las formas de expresión literaria, al dictar normas y reglas para la composición a partir de la descripción de diversos ejercicios retóricos. Pero sobre todo sirve para confirmar que esos tratados recogen toda una tradición, y, en el caso que nos ocupa, no sólo aseguran el empleo de la fábula en la enseñanza tanto por su carácter moral y didáctico como por su simplicidad de lenguaje y estilo, sino que, al mismo tiempo, adscriben ese tipo de narraciones a Esopo. ${ }^{25}$

En la cultura griega antigua, la historia de la fábula es inseparable de la formación y desarrollo de una leyenda en torno al creador y narrador de fábulas, potenciándose mutuamente ambos elementos: el nombre de Esopo justifica y garantiza la existencia de relatos parenéticos

\footnotetext{
${ }^{24}$ Babr. Proem. I 14-19: "Vas a aprender que esto es así, y a conocerlo, del viejo sabio Esopo que nos ha contado fábulas en el arte libre de las musas. A cada una de ellas yo ahora las voy a hacer florecer en mi memoria, recreándolas, para presentarte como un panal lleno de miel, suavizando los duros versos de los amargos yambos"./

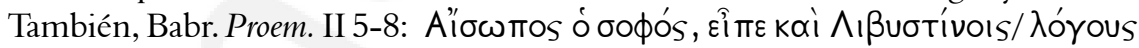

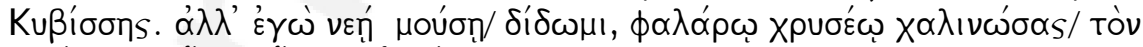

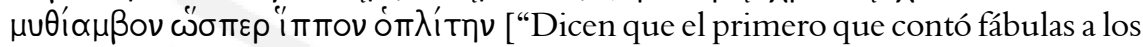
hijos de los griegos fue Esopo, el sabio, y que Cibises se las contó a los libios. Yo por mi parte las presento con una nueva forma poética, embridando con brida de oro el yambo de la fábula, como si fuese un caballo guerrero".]; y 13-16: ' $\gamma \omega^{\prime} \delta^{\prime} \varepsilon$

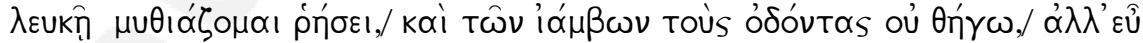

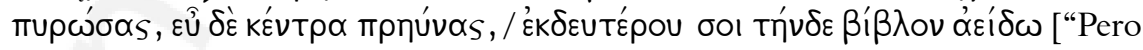
yo compongo las fábulas en una lengua transparente y no afilo los dientes de los yambos, sino que los templo bien al fuego y les emboto los aguijones para ofrecerte a ti este segundo libro".].

${ }^{25}$ Cf. Jedrkiewicz, op. cit., 1989.
} 
y apologéticos, principalmente con protagonistas animales, al mismo tiempo que el uso ininterrumpido de esa forma de expresión justifica y determina la continuidad de una leyenda sobre el fabulista, que cristaliza en época helenística en un relato biográfico próximo a la novela, la Vita Aesopi, ${ }^{26}$ cuya estructura ha sido analizada como la versión en una ficción narrativa biográfica de la estructura que caracteriza a la mayor parte de las fábulas de la principal colección, la colección Augustana. ${ }^{27}$

Por otra parte, la lectura de los tratados de retórica permite comprobar una muy estrecha correlación entre lo que esos manuales disponen y los escritores de la época; y la influencia de aquéllos sobre éstos se hace todavía más evidente cuando se compara el texto de unos y de otros, pues es entonces cuando mejor se aprecia la proximidad, de contenido y de expresión, entre las pautas prescritas en los compendios de carácter teórico y su aplicación en textos literarios. ${ }^{28}$

A este respecto, y entre los testimonios de época romana que hablan de Esopo, resulta especialmente instructivo Filóstrato, quien, además de mencionar al fabulista en la Vida de Apolonio de Tiana, ${ }^{29}$ le reserva, a él y al género por él cultivado, una de sus Descripciones de cuadros. En esta pieza filostratea, cuyo título es $M \hat{u} \theta o l,{ }^{30}$ las fábulas rondan y aman a Esopo, porque éste las trató con gran cuidado, aunque no fue su inventor, pues Hesíodo y Arquíloco, e incluso el propio Homero, ${ }^{31}$ ya se habían ocupado de ellas. Filóstrato indica así la antigüedad y tradición ininterrumpida del género, pero sugiere también diferencias en el modo de proceder de

\footnotetext{
${ }^{26}$ Cf. Rodríguez Adrados, op. cit., 1979 b, p. 94; Gómez, op. cit., 1987; Ruíz Montero, op. cit., p. 333-337; Ruíz Montero y Sánchez, op. cit., p. 243-252; Jouanno, op. cit., p. 14-22.

${ }^{27}$ Cf. Rodríguez Adrados, op. cit., 1992; Holzberg, op. cit., 1992; op. cit., 1996, p. 633-639.

${ }^{28}$ Cf. Fernández Delgado, op. cit., p. 278-281.

${ }^{29}$ Cf. Gómez, op. cit., 2002, p. 61-68.

${ }^{30}$ Philostr. Im. 1.3.

31 También Teón (Prog. 3) menciona a Homero como el primer fabulista. Las comparaciones épicas basadas en el mundo animal constituyen un germen de posteriores desarrollos narrativos convertidos más tarde en fábula - el león simboliza la fuerza, o el cervato el temor -; además, la Batracomiomaquia, de época helenística, pero atribuida a Homero, narra una batalla entre ranas y ratones, siendo éste el argumento de una fábula que Esopo mismo narra en la Vit. Aesop. 133 (G); cf. Jedrkiewicz, op. cit., 1989, p. 51; 305-306 y 326 (n. 68). No obstante, aunque también el texto homérico presenta ya animales que hablan, como el caballo de Aquiles (Il. XIX 407-418), la fábula se consideró inapropiada a la poesía heroica por su carácter popular; cf. Nøjgaard, op. cit., p. 449.
} 
estos poetas y el de Esopo. Para Homero, Hesíodo o Arquíloco la fábula es presentada como algo ajeno, como un objeto por el que se interesan e incorporan a su poesía. Esopo, en cambio, es quien - a juicio de Filóstrato

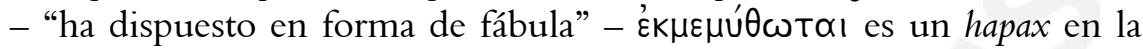

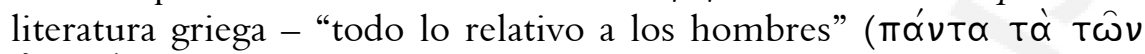
$\left.\alpha^{\prime} \nu \theta \rho \omega \dot{\pi} \omega v\right)$, y ha hecho a los animales participes de la palabra humana

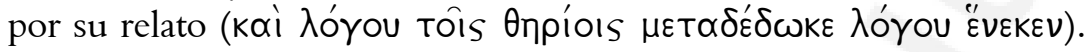

Filóstrato destaca asimismo el carácter ejemplar de la fábula como ya quería Hesíodo -, pero no descuida tampoco la otra función importante del apólogo animal, inseparable en cierto modo de aquél, es decir su uso como recurso e instrumento para censurar y atacar con fuerza los vicios y defectos del género humano, pues, como ya hizo Arquíloco y los cínicos más tarde, "Esopo censura con fuerza la codicia,

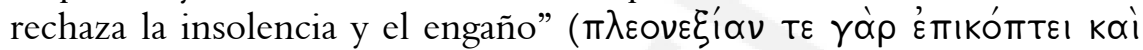

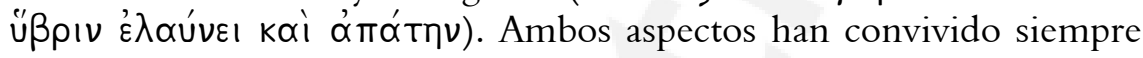
en la fábula y son determinantes, sin duda, en la finalidad última y fundamental del género: instruir, sea por ofrecer directamente modelos positivos de comportamiento, sea por mostrarlos de forma indirecta mediante la censura de los que son negativos, ya que la fábula - advierte Filóstrato - es el medio a través del cual "los chiquillos se hacen

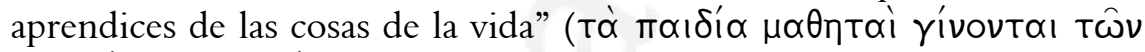

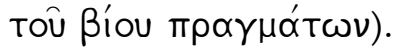

La segunda parte de la descripción se centra en Esopo, en el personaje, que es calificado de sabio. Las fábulas festejan al fabulista -

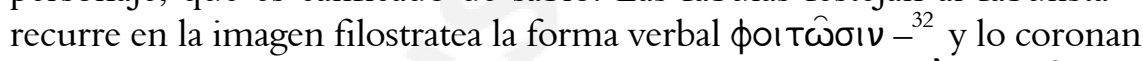

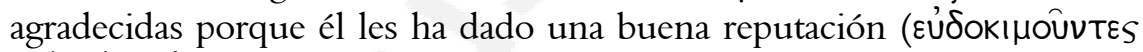

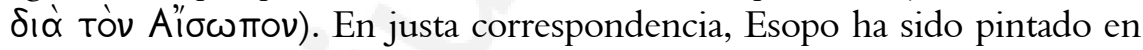
plena aplicacion a la actividad creadora y su tarea es explicada por Filóstrato con un término usado tradicionalmente como metáfora de la creación

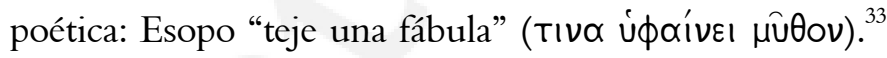

No obstante, en la descripción del cuadro no hay referencia alguna al aspecto físico del fabulista, a pesar de ser éste un elemento importante de su caracterización en el relato biográfico, ${ }^{34}$ donde una aterradora y despreciable apariencia acentúa todavía más la sutil inteligencia del deforme esclavo. Filóstrato se fija sólo en la sonrisa $\left(\mu \varepsilon ı \delta^{\prime} \propto \alpha \mu \alpha\right)$ de Esopo

\footnotetext{
${ }^{32}$ El verbo фoı тó $\omega$ significa frecuentar una escuela, a un amigo, e incluso mantener relaciones sexuales; cf. Chantraine, op. cit., p. 1220. El término фoıтnтrńs es explicado

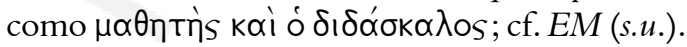

${ }^{33}$ Il. 3.212; Call. Ap. 57.

${ }^{34}$ Vit. Aesop. $1(\mathrm{G})$.
} 
y en su actitud reflexiva. El reir velado del fabulista se corresponde con el aspecto mordaz y crítico de sus obras, bajo las que se oculta siempre una sabia y seria meditación. Filóstrato advierte así que la fábula no es un puro entretenimiento ni su cultivo una mera diversión, un juego de

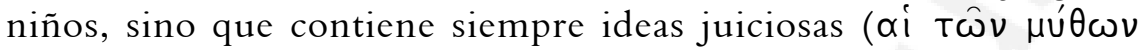

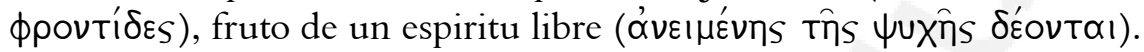
Esa libertad contrasta con la condicion servil de Esopo en la primera parte de la Vita, pero se traduce también en la libre y franca expresión -

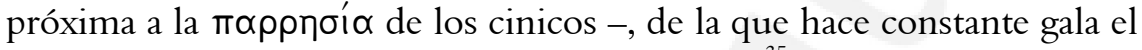
propio fabulista a lo largo del relato biográfico. ${ }^{35}$

El mérito del pintor ha sido - explica Filóstrato - representar de forma armónica la significación de las fábulas: hombres y animales mezclados en un mundo ficticio, en un espacio que Esopo modeló $\left(\sigma \cup \mu \pi \lambda \alpha^{\prime} \sigma \alpha \sigma \alpha\right)$ como si de una escena teatral se tratase y donde ejerce

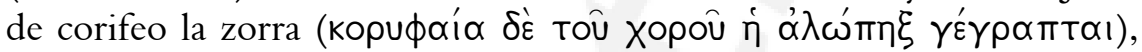
que actúa como servidora del fabulista en muchas de sus composiciones, calificadas ahora, siguiendo el símil teatral, de úто $\theta \dot{\varepsilon} \sigma \varepsilon \omega \nu$. Las fabulas, en efecto, "plantean" situaciones en las que la zorra, por su astucia y sabiduría, y el resto de animales, cada uno por unas cualidades distintivas propias, devienen prototipos; y es por ese carácter de repertorio - como los personajes-tipo del género cómico - que las fábulas se pueden usar con validez semejante en otros contextos. De ahí, la comparación con que Filóstrato concluye el texto: Esopo se sirve de la zorra "como la comedia de Davo" ( $\pi \lambda \varepsilon \varepsilon^{\prime} \sigma \tau \omega \nu$ u் nombre de esclavo propio de la comedia, lo recuerda, entre otros, el testimonio de Luciano, en contraposición a la tragedia: $\dot{\eta} \kappa \omega \mu \omega \delta_{i}^{\prime} \alpha \delta \dot{\varepsilon}$

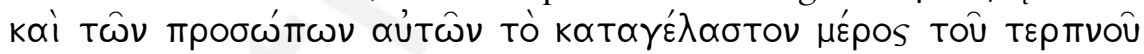

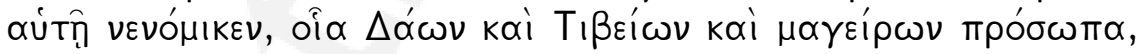
("La comedia, por su parte, se adjudica a sí misma el aspecto ridículo de sus personajes como parte de su encanto. Por ejemplo, las máscaras de los Davos, Tibeos y cocineros."). ${ }^{36}$

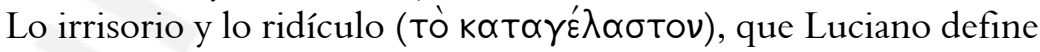
como propio de la comedia, constituyen, junto al ataque burlesco

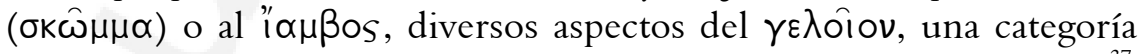
común a diversos géneros, entre los cuales también se incluye la fábula. ${ }^{37}$

\footnotetext{
${ }^{35}$ Cf. Gómez, op. cit., 2003 a, p. 320.

${ }^{36}$ Lucianus Salt. 29.

${ }^{37}$ Cf. Camerotto, op. cit., 1998, p. 108-109.
} 


\section{Luciano y la fábula}

Luciano se ha formado en la escuela y, por lo tanto, él mismo ha practicado los ejercicios preparatorios en los que, como hemos señalado, la fábula ocupa un lugar esencial. Luciano, no obstante, es un autor que, a pesar de ser buen conocedor de su tradición literaria y cultural, gusta de encontrar caminos propios, seguir huellas menos trazadas - como proponía el poeta helenístico - en un desafío constante a los modelos que le ofrece la literatura griega, a los cánones aprendidos.

Como otros autores de su época, también Luciano recurre a la fábula, pero no hace un uso excesivo de ella, al menos como unidad narrativa claramente diferenciada dentro del texto, y, por ello, el tratamiento literario de los apólogos clásicos no responde a un único patrón en la obra del samosatense; posiblemente sí a una misma intención. Luciano, en ocasiones, desarrolla y amplifica, a su modo, un tema esópico, incorporando así a la tradición de la fábula su propia parte de creación personal, pero, en general, la presencia de las fábulas que él mismo ha podido leer y practicar en las antologías de uso escolar se limita a una breve mención.

Consciente de que su público - oyente o lector - conoce las fábulas y ha aprendido cuál es la intención, finalidad o moraleja que de ellas deriva, Luciano no siente la necesidad de presentar todo el desarrollo dramático, escénico de la fábula, a pesar de que éste es precisamente un rasgo estructural que marca la diferencia entre la fábula y el proverbio, la $\chi \rho \varepsilon \hat{\imath} \alpha$, el relato etiologico o la anécdota. Múltiples son las variantes de la fábula, pero siempre se la identifica con un tipo de relato en el que se parte de una situación inicial, se produce una acción y se cierra con una conclusión que, por lo general, adopta la forma de imprecación, de exhortación, de soliloquio, a menudo de carácter proverbial, cuya función es resumir la moral y la enseñanza de la fábula, pues los promitios o epimitios de que suelen ir acompañadas son fruto de la conversión de la fábula en género antológico.

En la obra de Luciano, en cambio, sólo resta del relato primitivo, de la fábula original, un residuo proverbial o una comparación consagrada por el uso; y este proceder revela, una vez más, la auténtica apropiación por parte del escritor, formado por los rétores, de los modelos aprendidos, como señala Bompaire, al analizar la relación entre Luciano y el corpus esópico en el contexto más amplio del uso estilístico de otras formas de expresión también de marcado acento escolar. ${ }^{38}$

${ }^{38}$ Cf. Bompaire, op. cit., p. 443-469. 
No obstante, bien se trate de una simple alusión o de un desarrollo narrativo más amplio, Luciano también se fija en Esopo y distingue al personaje de la narración de una fábula o de la mención de alguna de ellas.

Ello ocurre, por ejemplo, en el episodio elíseo de Relatos verídicos, en el libro segundo, donde Luciano presenta en forma de catálogo a los habitantes de la Isla de los Bienaventurados, y describe cómo viven en ella esos ilustres muertos: semidioses y héroes de Troya, griegos y bárbaros, reyes y tiranos, poetas y filósofos. ${ }^{39}$ En esa descripción se percibe bien el guiño de Luciano a la tradición griega, literaria y cultural, pues su Hades feliz, gracias a la aproximación lúdica cuando no paródica del samosatense, ${ }^{40}$ se convierte en un escenario por donde desfilan los más eminentes nombres del imaginario griego.

Luciano practica aquí un arte claramente alusivo: le basta con una breve pincelada para presentar a los personajes y, con ella, dejar constancia también de su personal juicio sobre ellos o sobre el modo como han sido consagrados por la propia tradición. Así lo ilustran, entre muchas otras referencias, las escenas del juicio de Radamantis o la escueta mención de Estesícoro tras la que se insinúa la famosa palinodia del poeta de Himera. ${ }^{41}$ Atención especial merece el trato dispensado a Homero, cuyas obras constituyen el principal entretenimiento en el festín de los bienaventurados, pero sobre todo resulta interesante la información que el protagonista recaba, de primera mano, del propio poeta y que lo autoriza a desmentir algunas de las creencias más arraigadas en torno al poeta épico, como puede ser el tema de su ceguera. ${ }^{42}$ Los héroes, a su vez, son los protagonistas de los juegos celebrados en honor de la muerte y, por supuesto, ocupan lugar preeminente Aquiles, Teseo y Heracles; ${ }^{43}$ y Helena por su reiterada infidelidad a Menelao es la causante de la expulsión del protagonista de la isla antes del tiempo previsto, ya que la espartana lo involucra a él y a sus compañeros en un episodio amoroso, con huida incluida, al estilo de las que abundan en las novelas griegas. ${ }^{44}$

${ }^{39}$ Lucianus HV II 6-28.

${ }^{40}$ Cf. Cabrero, op. cit., p. 201-236.

${ }^{41}$ Lucianus HV II 6-9; 15.

${ }^{42}$ Lucianus HV II 20.

${ }^{43}$ Lucianus HV II 22.

${ }^{44}$ Lucianus HV II 25-27. Sobre este episodio, véase Mestre, Gómez y Vintró, op. cit., p. 573-579. 
Pero, sin duda alguna, en el festín del Elíseo brillan con luz propia los filósofos, contra cuya actitud Luciano arremete también aquí, como en otras tantas de sus obras, prácticamente sin distinción de escuela o tendencia, ${ }^{45}$ para denunciar su falsedad, extravagancia e incluso hipocresía, como ocurre con Diógenes de Sínope o Pitágoras, ${ }^{46}$ sin olvidar la lograda caricatura de que son objeto Sócrates y Platón: uno por su actitud irónica y su trato con hermosos jóvenes; ${ }^{47}$ el segundo, aunque ausente de la isla, recibe su parte de burla a través de sus seguidores, quienes, por exceso de dedicación a la especulación teórica, retardaban su llegada y todavía andaban discutiendo si existía una isla semejante. ${ }^{48}$

Es en este mismo contexto donde Luciano menciona a Esopo, quizá porque se trata de un sabio o forma parte de los Siete Sabios de la tradición griega y con ellos puede banquetear: ${ }^{49}$ oi $\mu \varepsilon^{\prime} \nu \tau o l ~ \alpha \mu \phi^{\prime}$ 'Apíotıாто́

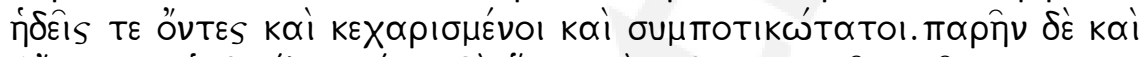

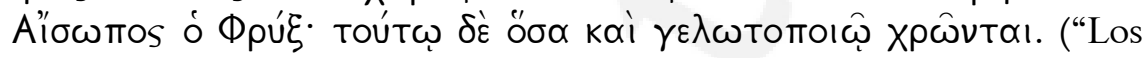
seguidores de Aristipo y de Epicuro ocupaban allí los lugares preferentes, pues son amables, agradables y los mejores compañeros de banquete. También estaba Esopo, el frigio. Lo utilizaban solamente como bufón.") ${ }^{50}$

Con esta escueta referencia a Esopo, Luciano se suma a la tradición del origen frigio del fabulista, tal como recoge la versión principal de la

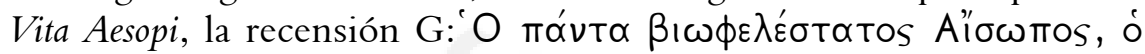

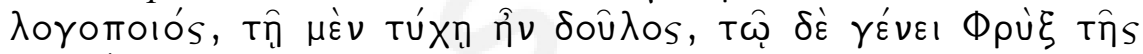
Фpurias ("El utilísimo Esopo, el fabulista, por culpa del destino era esclavo, por su linaje, frigio, de Frigia...”). ${ }^{51}$

\footnotetext{
${ }^{45}$ Cf. Georgiadou y Larmour, op. cit., p. 195-199, donde se señala que Luciano en su crítica exceptúa al Peripato. No obstante, Luciano siempre arremete con especial dureza contra los filósofos cuando se trata de censurar el indigno comportamiento de éstos en el banquete; cf. Gómez y Vintró, op. cit., p. 199-203; Gómez y Jufresa, op. cit., p. 104-108; Gómez, op. cit., 2011, p. 248-252.

${ }^{46}$ Lucianus HV II 18; 21.

${ }^{47}$ Lucianus HV II 17; 19.

${ }^{48}$ Lucianus $H V$ II 17-18.

${ }^{49}$ Plu. Mor. 146 b-164 d, donde el fabulista también participa en el convite de Sabios celebrado en Corinto, en la corte de Periandro, donde ocupa, no obstante, un asiento inferior; cf. Jedrkiewicz, op. cit., 1997.

${ }^{50}$ Lucianus HV II 18.

${ }^{51}$ Vit. Aesop. 1 (G); Gómez, op. cit., 1990-1992.
} 
Sin embargo, en el sumario esbozo que Luciano hace del fabulista, resulta quizás mucho más interesante aquí el uso del término $\gamma \varepsilon \lambda \omega \tau$ тाоо reconoce un elemento importante - aunque relativamente reciente en la tradición esópica - como es la caracterización física del personaje, pues en el relato biográfico una aterradora y despreciable apariencia sirve para acentuar todavía más la sutil inteligencia del deforme esclavo:

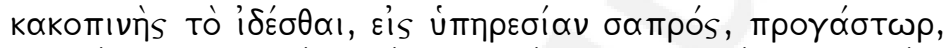

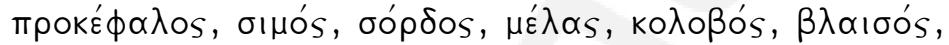

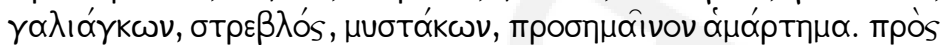

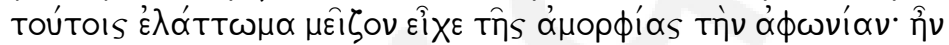

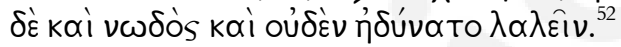

El adjetivo $\gamma \varepsilon \lambda \omega t o t \pi o$ ós es usado por Platon referido a Tersites en un pasaje de la República, en el mito de Er, donde el antihéroe épico es asociado al animal que, según Hermógenes, ${ }^{53}$ y como ilustran muchas fábulas, mejor describe las acciones de los hombres en su aspecto, cabe

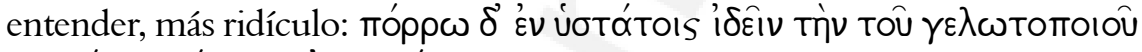

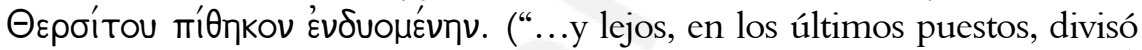
el alma del hazmerreír Tersites, que se revestía con un cuerpo de mono.” ${ }^{54}$

No obstante, dicho adjetivo también puede entenderse en el texto de Luciano no sólo en el sentido de "quien hace reír", porque él mismo es causa y objeto de risa, sino con valor factitivo, es decir, porque hace recaer la acción de reír en algo o en alguien, como bien corresponde a la función crítica de las fábulas. ${ }^{55}$ Por otra parte, si ya Heródoto había definido al

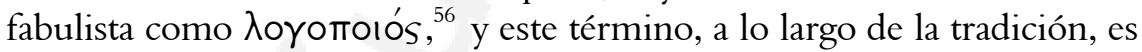

\footnotetext{
${ }^{52}$ Vit. Aesop. 1 (G): "De imagen desagradable, inútil para el trabajo, tripudo, cabezón, chato, tartaja, negro, canijo, zancajoso, bracicorto, bizco, bigotudo, una ruina manifiesta. El mayor defecto que tenía a parte de su fealdad, era su imposibilidad de hablar; además era desdentado y no podía articular"./ La incapacidad para hablar que muestra Esopo al inicio del relato biográfico es subsanada por la diosa Isis, ya que ésta concede al esclavo la facultad de la palabra como recompensa por haberse mostrado humilde y generoso con ella; cf. Gómez, op. cit., 1989, p. 218-219.

${ }^{53}$ Hermog. Prog. 1.2 .

${ }^{54}$ Pl. R. 620 c; y supra n. 21.

${ }^{55}$ Gómez, op. cit., 2000, p. 431-438, para un análisis de la función del reír (del verbo $\gamma \varepsilon \lambda \alpha^{\prime} \omega$, del substantivo $\gamma \varepsilon ́ \lambda \omega s$, y de sus compuestos y derivados) en el conjunto del copus esópico.

${ }^{56}$ Hdt. II 134.
} 
reemplazado, con valor equivalente, por $\mu \cup \theta 0 \pi$ oı́s para referir la actividad propia de Esopo, como muestran algunos testimonios, ${ }^{57}$ bien puede ser que Luciano - a quien gusta de jugar con las palabras $-{ }^{58}$ utilice en la caracterización del fabulista un vocablo que, desde el punto de vista formal, es un calco de los que suelen describir la tarea de Esopo: el hacedor

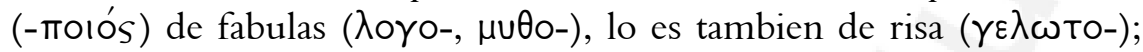
pero, ademas, Luciano recupera con este compuesto, desde el punto de vista de su contenido, de su significado, una ambigüedad relativa a Esopo que remonta a Aristófanes mismo.

En un pasaje de Avispas, Filocleón explica cuántas y diversas son las adulaciones a las que se ve sometido un juez:

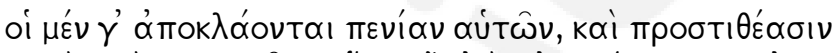

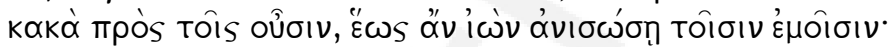

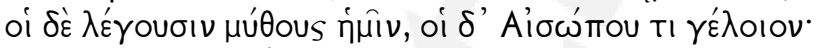

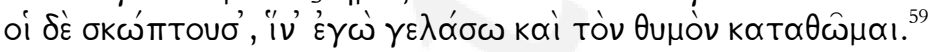

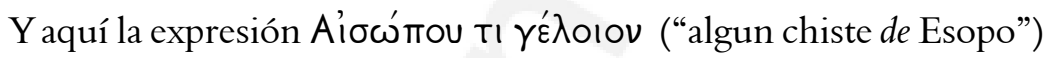
tal vez pueda apuntar ya hacia esa dualidad sujeto/ objeto, como se confirma más adelante, en esa misma comedia, cuando Bdelicleón recomienda a su antagonista:

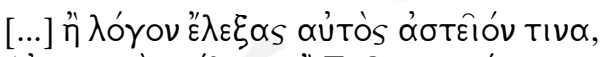

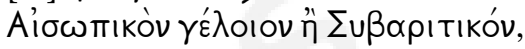

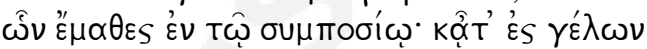

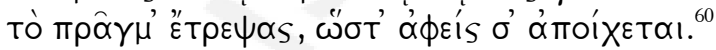

Pero Filocleón interpreta que se trata de un chiste sobre Esopo:

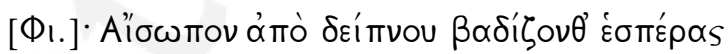

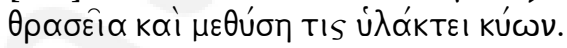

\footnotetext{
${ }^{57}$ Vit. Aesop. 1 (W) [= Test. 1b Perry]; Zenob. V 16 [= Test. 37 Perry].

${ }^{58}$ Cf. Casevitz, op. cit., p. 77-86.

${ }^{59}$ Ar. V.564-568: "Unos se lamentan de su pobreza y la ponen de pretexto; otros nos cuentan fábulas; otros, algún chiste de Esopo; otros se ponen a hacer gracias para que yo me ría y se me bajen los humos".

${ }^{60}$ Ar. V. 1258-1261: "Pronunciar uno de esos discursos finos - algún chiste de Esopo o de Síbaris - que has aprendido en el banquete; luego echas el asunto a risa y te sueltan y te vas".
} 


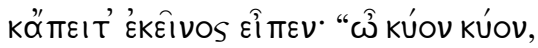

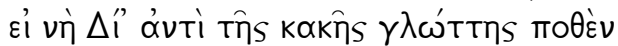

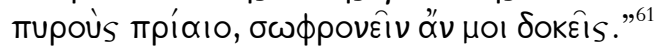

La respuesta de Filocleón confirma la indiscutible autoridad de Esopo que alimenta la generación del corpus fabulístico griego, de donde, en épocas sucesivas y para géneros literarios diversos, filósofos, poetas o prosistas tomarán modelos de referencia: Sócrates mismo reconoce haber aprendido las fábulas de Esopo y se dedicaba a versificarlas mientras aguardaba la muerte. ${ }^{62}$

Por ello no resulta extraño que casi todas las fábulas contenidas en la obra de Luciano - en la forma o extensión que sea - pertenecen a la colección esópica y, principalmente, a la recensión más antigua. Hay, sin embargo, tres excepciones: El hombre que contaba las olas, ${ }^{63}$ El caballo desbocado ${ }^{64}$ y Los monos disfrazados. ${ }^{65}$

En el caso de la fábula, buena parte del éxito de esa apropiación de modelos a la que antes hacíamos referencia es cifrada por los autores de época postclásica - y, por lo tanto, Luciano y sus coetáneos no son una excepción - en vincular al nombre de Esopo las fábulas que introducen en sus obras, bien sea adaptándolas del acervo tradicional, bien sea inventándolas ellos mismos.

En el diálogo titulado Icaromenipo o el que vuela por encima de las nubes, Menipo - el filósofo cínico que en manos de Luciano deviene una creación paródica del estereotipo literario que sus obras contribuyeron a crear $-{ }^{66}$ se muestra desencantado ante las vagas y contradictorias teorías filosóficas sobre el cosmos y los dioses, y ante la mezquindad e inseguridad de las empresas humanas. Desconcertado por todo ello, cree que sólo conseguirá liberarse de su total perplejidad y desconocimiento de las cosas etéreas, celestiales y divinas, si sube hasta el cielo, dotado de alas:

\footnotetext{
${ }^{61}$ Ar. V. 1401-1405: Filocleón - Una noche que Esopo volvía de cenar, se puso a ladrarle una perra atrevida y borracha, y entonces él dijo: "Ay, perra, perra, si a cambio de tu mala lengua pudieras conseguir alimentos en algún lugar, me parecería que obras sensatamente".

${ }^{62}$ Pl. Phaed. 60 c; 61 b.

${ }^{63}$ Lucianus Herm. 84.

${ }^{64}$ Lucianus Cyn. 18.

${ }^{65}$ Lucianus Pisc. 36, Apol. 5. El tema de esta fábula sí se encuentra ya en las colecciones, pero con otros protagonistas (Aesop. 50, La comadreja y Afrodita).

${ }^{66}$ Cf. Branham, op. cit., p. 14-28; Camerotto, op. cit., 2009, p. 42-47.
} 


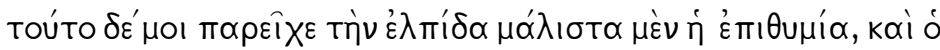

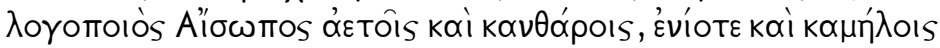

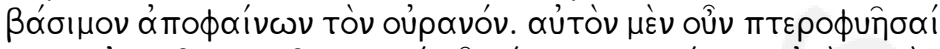

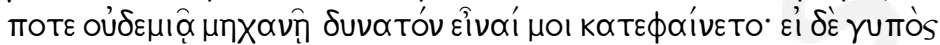

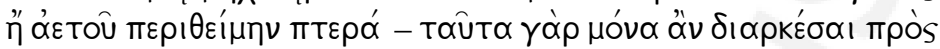

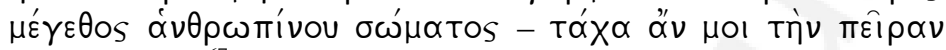

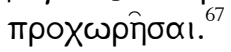

La misión que se propone Menipo no sólo depende, pues, de su voluntad, sino que está avalada por la tradición. Esas "águilas y escarabajos" hacen, sin duda alguna, referencia a una fábula presente en las colecciones, El águila y el escarabajo y que en la Vita Esopo mismo narra en una versión extensa, a modo de parábola, ante los habitantes de Delfos justo antes de morir. ${ }^{68}$ Como Luciano, también Aristófanes alude a esa fábula, sin explicarla, y la pone en boca del fabulista igualmente en el contexto délfico:

Filocleón - Cierto día a Esopo los de Delfos...

BDELICLEÓN - Me importa un bledo.

FILOCLEÓN - ... acusaban del robo de una copa del dios, y él les dijo que una vez un escarabajo...

BDELICLEón - iAy de mí! Voy a acabar de una vez contigo y con tus escarabajos. ${ }^{69}$

En cuanto a los camellos, Luciano puede estar pensando también en alguna fábula del corpus esópico, pues El camello que quiso tener cuernos ${ }^{70}$ narra cómo este rumiante llega hasta el cielo para pedir a Zeus unos cuernos iguales a los del toro. De este modo, Luciano insiste en el carácter irreal de la narración esópica - que, sin embargo, va a permitir a Menipo llegar hasta el dios mismo -, en virtud de la cual incluso un animal tan poco apto para volar como un camello se atreve a hacerlo,

\footnotetext{
${ }^{67}$ Lucianus Icar. 10: "El afán de lograrlo - afirma Menipo - motivaba mi esperanza, mas también el fabulista Esopo al revelar que el cielo es accesible a águilas y escarabajos, y en ocasiones incluso a camellos. Llegar yo a echar alas no me parecía en modo alguno posible; en cambio, de aplicarme alas de buitre o águila - pues ésas serían las únicas adecuadas al volumen de un cuerpo humano -, tal vez podría tener éxito en mi intento".

${ }^{68}$ Aesop. 3; Vit. Aesop. 135-139 (G).

${ }^{69}$ Ar. $V$. 1446-1448. El comediógrafo retoma esta fábula, al menos, en otras dos ocasiones: Pax 129-134; Lys. 691-695.

${ }^{70}$ Aesop. 117.
} 
aunque con resultados bien adversos para sus intenciones, ya que Zeus no sólo no le concedió los cuernos, sino que le quitó parte de las orejas. La fábula del camello sirve, asimismo, de anticipo de lo que va a ocurrirle a Menipo por querer desafiar su naturaleza humana: la sentencia de Zeus es que "le sean cortadas las alas para que nunca pueda regresar aquí, y Hermes lo baje hoy a la tierra".

Luciano, muy al gusto cínico - entendiendo aquí el término no en sentido doctrinal, de escuela, sino distintivo de una forma de vida $-{ }^{72}$ se muestra poco indulgente contra todo aquello que suene a superficialidad y falsedad, y su pluma satírica ridiculiza sin miramientos todo tipo de convenciones. No obstante, sus dos objetivos de ataque predilectos son los filósofos y los oradores. ${ }^{73}$ En la obra de Luciano es recurrente la censura mordaz contra los filósofos, aunque esta crítica no suele ir dirigida contra la ideología de las distintas escuelas filosóficas, sino fundamentalmente contra el comportamiento falso e hipócrita que exhiben sus representantes, y encuentra su razón de ser en variados motivos: glotonería, tosquedad, vicios de todo tipo y, en general, cualquier muestra de comportamiento indigno por parte de quienes hacen alarde de gran saber y explican a los demás cómo actuar, pero sin aplicárselo ellos mismos.

Ante esa situación, pues, no es extraño que doña Filosofía se lamente y se queje del descrédito que padece por culpa de una creciente e ignorante multitud de falsos imitadores, los cuales, bien provistos de audacia, estupidez y desvergüenza, se ejercitan en nuevos insultos y los tienen siempre prestos en su boca. Todos ellos - explica Filosofía a Zeus -

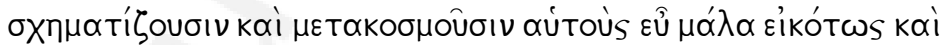

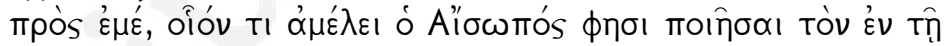

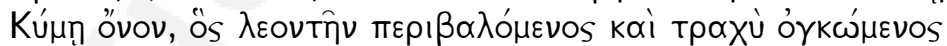

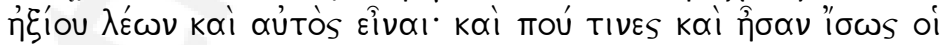

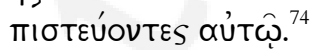

En la fábula esópica El asno disfrazado de león el presuntuoso animal es desenmascarado por la zorra, a la cual, en su estupidez, el burro pretendía amedrentar: "Sabe bien" - replica la zorra - "que también yo

\footnotetext{
${ }^{73}$ Cf. Hall, op. cit., p. 252-309; Gómez, op. cit., 2003b, p. 277-284; Gómez y Jufresa, op. cit., p. 108-111; y Karavas, op. cit., p. 158-159, sobre la parodia de los rétores áticos en la obra del samosatense.

${ }^{74}$ Lucianus Fug. 13: “Componen su figura y se disfrazan lo mismo que Esopo cuenta del asno de Cumas, que se puso una piel de león y empezó a rebuznar con violencia, pretendiendo ser también él un león. Y, sin duda, había algunos que le creían”./Brandão, op. cit., p. 51-64.
} 
me habría asustado si no te hubiera oído rebuznar" ${ }^{75}$ Esta fábula según reza el epimitio - ilustra la conducta de hombres poco instruidos

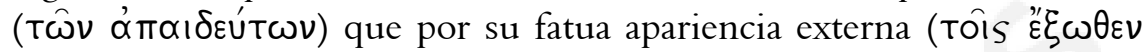
Túфols) creen ser alguien, pero se delatan por su verborrea (úmò tîs

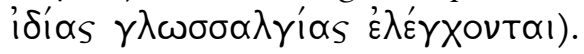

\section{El Pseudologista}

En los ejemplos citados la narración del apólogo animal es escueta por parte de Luciano y la validez del modelo citado está avalada por el nombre de Esopo; asimismo, en ambos casos la fábula esópica es utilizada para revelar postizas apariencias, para denunciar transgresiones de límites naturales. Y a ambos motivos animales - el escarabajo y el asno -, ahora sin el nombre del fabulista, recurre también Luciano en Pseudologista cuando enumera con ejemplos las dificultades que el $\gamma o$ narrativo - el sofista auténtico - va a encontrar para instruir, aunque sea mediante una invectiva, a un hombre tan ignorante, perverso y osado como ese necio orador que se ha atrevido a plagiarle:

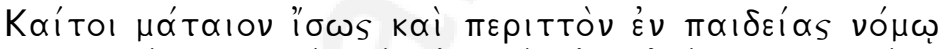

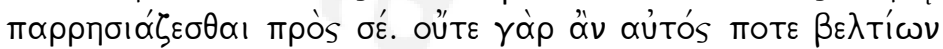

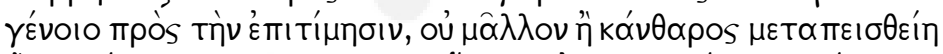

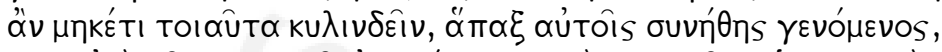

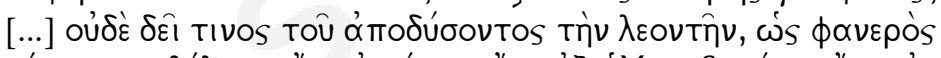

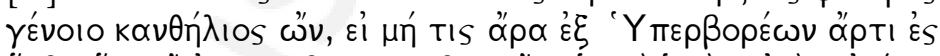

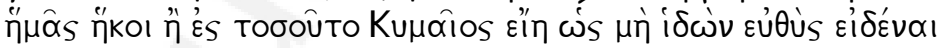

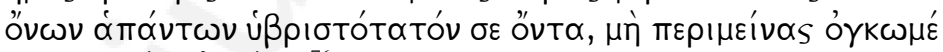

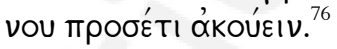

Así, la insolencia y la presunción del orador interpelado son explicadas y debidamente reconvenidas a lo largo de la obra, pero en el

\footnotetext{
${ }^{75}$ Aesop. 188; Babr. 139. Este motivo, como tantos otros de las fábulas, se encuentra recogido también en los refranes: Zen. VI 28, Apostol. IV 26.

${ }^{76}$ Lucianus Pseudol. 3: "En realidad, tal vez sea vano e inútil hablarte con franqueza en tono educativo. Pues tú nunca podrías mejorar ante la censura, no más que un escarabajo se dejaría persuadir de que ya no haga rodar tales bolas, una vez ya se ha acostumbrado a ellas, [...] Tampoco se requiere a nadie que te quite la piel de león para que se haga evidente que eres un asno de carga, a no ser que haya venido junto a nosotros recientemente, procedente del país de los Hiperbóreos, o sea hasta tal punto un palurdo de Cumas que, viéndote, no sepa que eres el más insolente de todos los asnos, sin que tenga que esperar a oírte rebuznar".
} 
prólogo pueden ya ser descritas y sintetizadas, con pocas palabras, gracias al uso, por parte de Luciano, de símiles animales.

¿En qué aspectos, con qué conducta y actitudes, sobre qué argumentos demuestra el yo narrativo de Pseudologista la ineficacia y la maldad del sofista plagiador? Los motivos de censura, que afectan tanto la profesión como la conducta de ese crítico falaz, son de diversa índole, como Luciano explica a lo largo de la obra. Ahora bien, en los capítulos iniciales, antes de que el sofista plagiado relate los pormenores de la declamación, precise el significado del término ơ тофрớs y arremeta contra las costumbres depravadas e inmorales de su adversario, hay una deliberada declaración de intenciones por parte del narrador en cuanto al género literario sobre el que, en gran parte, justificará su exposición, pero de sobras es conocido cómo Luciano gusta, precisamente, de innovar en el uso de esos géneros. ${ }^{77}$ Esa voluntad de inscribir, al menos en cuanto a contenido, las palabras del sofista en una determinada tradición literaria puede observarse a partir de la recurrencia de algunos términos, por la mención reiterada de algunos autores griegos, como son Arquíloco, Hiponacte y Semónides, cuya presencia se concentra en los capítulos iniciales de esta obra con una insistencia inusual en el corpus lucianeo.

Los tres poetas mencionados cultivaron una determinada poesía, el yambo, con la que se identifica no sólo una forma poética - una precisa forma y estructura métrica, sino también, en sentido más amplio - y, por encima, pues, de consideraciones estrictamente formales - un contenido específico: la burla, el ataque verbal, la invectiva. Sirve, en definitiva, la poesía yámbica para denunciar adversarios, para comprometer actitudes. A lo largo de la cultura griega esa forma de expresión poética permeabiliza otros géneros, otras formas literarias, a las que inunda y cede su contenido. Es por ello posible rastrear testimonios de cuño yámbico, por así decirlo, también en otras formas literarias, incluidas las expresadas en prosa.

Al invocar a Arquíloco, a Hiponacte y a Semónides, Luciano legitima con la autoridad de los poetas arcaicos - reconocida ya por la comedia $-{ }^{78}$ el ataque verbal que el yo narrativo de Pseudologista se dispone a pronunciar contra su adversario, de la misma forma que cuando usa un relato ejemplar relacionado con el mundo animal se ampara en el prestigio de Esopo.

\footnotetext{
${ }^{77}$ Cf. Mestre y Gómez, op. cit., 2001, p. 111-112.

${ }^{78}$ Cf. Camerotto, op. cit., 1998 , p. 87.
} 
No obstante, al analizar la presencia de estos poetas yámbicos en el corpus lucianeo, exceptuando Pseudologista, se constata que el testimonio de los yambógrafos es muy reducido - por no decir inexistente - en la obra del samosatense, a pesar de que Luciano practica él mismo muy a menudo la diatriba, compone sátiras, o lanza invectivas y burlas hacia determinados personajes de su entorno, de su propio tiempo, e incluso de la tradición mítica y literaria griega.

Arquíloco e Hiponacte sólo aparecen - y juntos - en Contra el ignorante que compraba muchos libros [=Adversus Indoctum], que constituye, también como Pseudologista, una dura invectiva, dirigida en este caso contra un conciudadano del autor, que gasta cuantiosas sumas de dinero en la adquisición de libros, sin criterio alguno y sólo para llamar la atención de sus aduladores y del propio emperador:

Con gusto te preguntaría: ¿teniendo tantos libros cuáles de ellos lees especialmente? ¿Los de Platón? ¿Los de Antístenes? ¿Los de Arquíloco? ¿Los de Hiponacte? ¿O esos los desprecias, mientras tienes a los oradores muchísimo más a mano que a éstos? Dime, ¿lees el discurso de Esquines contra Timarco? Sin duda conoces y comprendes todas y cada una de esas obras, pero ite sumergiste a fondo en Aristófanes y Éupolis?... ${ }^{80}$

Del poeta de Amorgos y autor del yambo contra las mujeres no hay, en cambio, en la obra del samosatense ninguna otra mención más que la de Pseudologista:

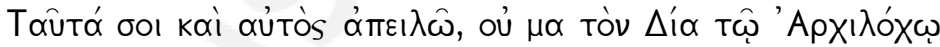

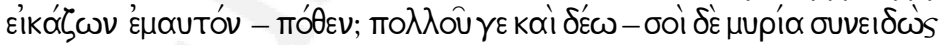

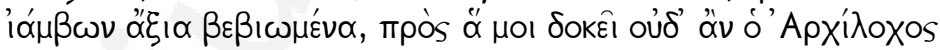

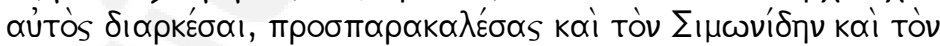

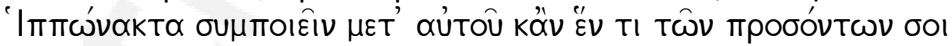

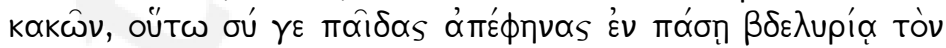

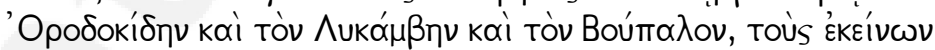
'ó́pßous. ${ }^{81}$

\footnotetext{
${ }^{79}$ Cf. Branham, op. cit., p. 9-63.

${ }^{80}$ Lucianus Ind. 27.

${ }^{81}$ Lucianus Pseudol. 2: "Esta misma amenaza te lanzo yo a ti, no - por Zeus - porque me compare a Arquíloco - ¿de qué? ini mucho menos! -, sino porque me he dado cuenta de que en ti hay miles de vivencias dignas de yambos, para las cuales me parece que ni el mismo Arquíloco daría abasto, ni aun convocando también a Simónides y a Hiponacte para que colaboren con él en describir siquiera uno solo de tus defectos característicos, tal como tú hiciste aparecer cual niños, con toda su perversidad, a Ordócides, a Licambes y a Búpalo, es decir los yambos a ellos dedicados”.
} 
Parece, pues, que Arquíloco es - a juicio de Luciano - el yambógrafo por excelencia, o bien el más eficaz para los propósitos del samosatense, pues el poeta de Paros usó mucho las fábulas, ${ }^{82}$ como recuerda el autor de la invectiva ya en sus primeras palabras:

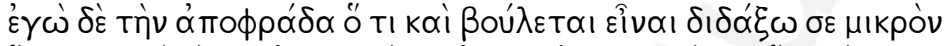

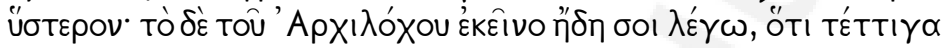

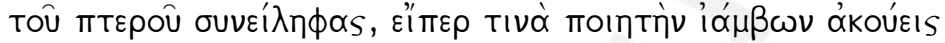

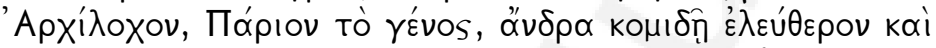

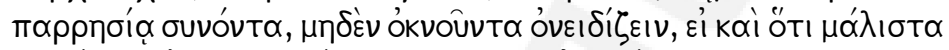

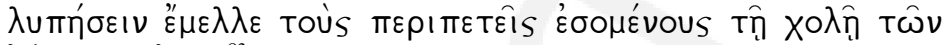
ió $\mu \beta \omega \nu$ aútoû.
\end{abstract}

Luciano afirma así que las fábulas contenidas en los versos de Arquíloco sirven para herir a sus adversarios, porque su poesía se dirige al insulto y al escarnio, burlándose e injuriando a las víctimas del

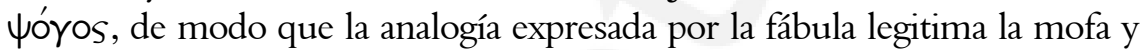
la infamia de quien es objeto de ella. ${ }^{84}$ Como Arquíloco, Luciano vaticina así a su víctima concreta - con independencia de si se trata de una polémica real o "literaria" - una mala sorpresa a través de un referente animal: la cigarra resulta peligrosa cuando se la agarra por el ala, ya que responde con un canto continuo; es decir, con un vituperio sin tregua. Por otra parte, tampoco renuncia a introducir uno de los temas de su ataque: la ignorancia de su adversario, al no estar seguro de que éste entienda la referencia, sepa quién es Arquíloco y pueda así comprender la eficacia de su invectiva, habida cuenta de que la base de una parodia está en la intertextualidad y, si el destinatario de la burla carece de educación, de paideia, el juego intertextual no puede funcionar. ${ }^{85}$ Eso de "...si es que has oído hablar de Arquíloco..." remite, posiblemente, al verso aristofánico donde la falta de instrucción se equipara a desconocer a Esopo: "Eres ignorante por naturaleza y poco curioso, y no

\footnotetext{
${ }^{82}$ Cf. Degani, op. cit.; Miralles y Pòrtulas, op. cit.; Jedrkiewicz, op. cit., 2002, p. 27-32.

${ }^{83}$ Lucianus Pseudol. 1: "Yo mismo, lo que quiere decir 'nefasto', te lo enseñaré un poco más adelante; pero ahora ya te voy a decir aquello de Arquíloco, que 'has agarrado a la cigarra por el ala', si es que has oído hablar de Arquíloco, un poeta yámbico, nacido en Paros, hombre completamente libre y acostumbrado a la libertad de palabra, que no dudaba en insultar aun cuando causara gran ofensa a cuantos estaban a punto de sucumbir a la bilis de sus yambos"./ La cita arquiloquea corresponde a fr. 223 (West).

${ }^{84}$ Cf. Brown, op. cit., p. 59-69.

${ }^{85}$ Cf. Camerotto, op. cit., 1998, p. 285.
} 


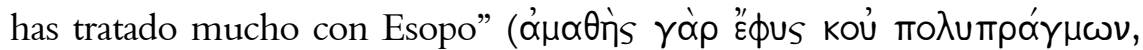

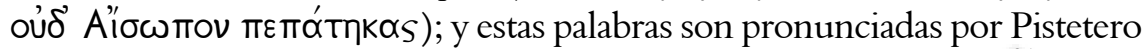
precisamente cuando se dispone a explicar la fabula de la alondra. ${ }^{86}$

Y es también esa falta de letras, unida y agravada por una conducta indigna, la que Luciano resume con la naturaleza y actitud del grajo:

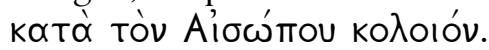

\section{El grajo de Luciano}

El grajo es un animal de presencia escasa en el corpus esópico, pues únicamente aparece en siete fábulas. ${ }^{87}$ Sólo en una de ellas, El pavo real y el grajo, ${ }^{88}$ éste da muestras de una cierta inteligencia, mientras que en el resto de apólogos es, con diferencia, el perdedor del relato, porque suele ser claramente superado por sus antagonistas en inteligencia, y sobre todo deviene objeto de escarnio y de ridículo por querer aparentar lo que no es, por querer franquear los límites de su naturaleza. Así, la falta de inteligencia del grajo se hace patente cuando éste se enfrenta a la astuta zorra, la cual descubre con facilidad que el grajo miente al intentar justificar de forma inadecuada por qué no come unos higos: "Estás equivocado, amigo" - le dice la zorra -, "al fiarte de la esperanza, que sabe alimentar las ilusiones, pero en modo alguno da de comer."

De igual modo, cómo la inoportunidad de una acción puede acarrear grandes males se pone de manifiesto cuando un grajo, al ser capturado, intenta escapar de su cautiverio, pero queda atrapado en unas ramas y entonces ya no puede volar, sino sólo esperar la muerte: "iQué desgraciado soy!" - exclama - "Yo, que por no aguantar la esclavitud de los hombres, sin darme cuenta, yo mismo me he quitado la posibilidad de salvarme." 90

Hay otras cuatro fábulas con un grajo como protagonista cuyo motivo común es que el ave no quiere admitir su propia condición y, por ello, huye de sus congéneres, o bien esconde su apariencia, con resultados siempre negativos para él. La primera forma de proceder la ilustran tres fábulas, El grajo y los cuervos, El águila, el grajo y el pastor, y El grajo y las

\footnotetext{
${ }^{86}$ Ar. $A v \cdot$ 471-474.

${ }^{87}$ Aesop. 2, 101, 123, 126, 129, 131 y 219 Perry.

${ }^{88}$ Aesop. 2, 219 Perry, El pavo real y el grajo.

${ }^{89}$ Aesop. 2, 126 Perry, El grajo y la zorra.

${ }^{90}$ Aesop. 2, 131 Perry, El grajo que se escapó.
} 
palomas, ${ }^{91}$ en las que, con antagonistas distintos, se plantean situaciones semejantes - el desprecio de los demás grajos y el deseo de parecerse a las palomas o de imitar a la poderosa águila - con un desenlace también idéntico.

En dos de estos relatos el grajo, por preferir a desconocidos, que no lo aceptan, acaba siendo expulsado también de entre los suyos: los cuervos porque ignoran su forma y su voz, las palomas al oír su graznido; y en el tercero, al querer cazar como un águila, queda atrapado entre los vellones de un carnero, de modo que un pastor lo captura y le recorta las alas remeras, impidiéndole volar de nuevo. El pastor, al ser interrogado por sus hijos sobre qué tipo de pájaro era el que había capturado, responde: "Por lo que yo tengo bien entendido, un grajo; pero por lo que él se pretende, un águila." Asimismo, la fábula de las palomas combina también el motivo de la falsa apariencia, pues el grajo para lograr su objetivo - estar bien nutrido como las palomas - se blanquea para asimilar su aspecto al de éstas, pero al ser rechazado por las palomas y regresar entre los suyos, precisamente a causa de su nuevo color tampoco es reconocido por los demás cuervos.

$\mathrm{Y}$ es esa voluntad de engañar a sabiendas, escondiendo el aspecto que por naturaleza le corresponde, la que provoca la derrota del grajo también en la fábula que Luciano glosa en la comparación de Pseudologista, pues no cabe duda de que "como el grajo de Esopo" - en relación a ese

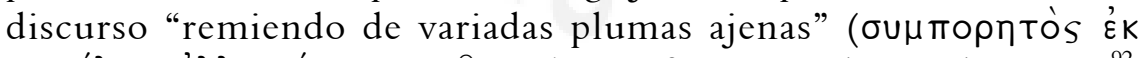

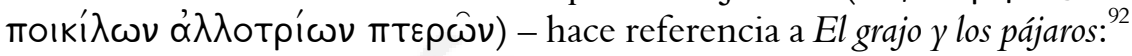

Quería Zeus designar rey entre los pájaros y les fijó un día para que compareciesen ante él. El grajo, consciente de su propia fealdad, mientras se paseaba entre los pájaros, iba recogiendo las plumas caídas, y se las colocaba encima. Cuando llegó el día, convertido en un

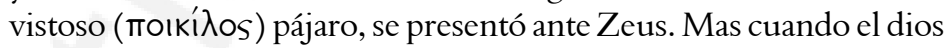
estaba dispuesto a elegirlo rey en razón de su belleza, los pájaros, irritados, rodearon al grajo y cada uno le quitó la pluma que era suya. Yasí sucedió que el grajo, despojado, volvió a ser grajo.

El sofista prestigioso es, en el texto de Luciano, quien, como los pájaros en la fábula, se dispone a desenmascarar, quitándole las abigarradas plumas de su falsa oratoria, al impostor de sofista, el cual es además un ignorante - como ignorante, por pretencioso, demuestra ser el grajo en fábulas analizadas -, para que no merezca ser llamado sofista ni siga engañando al público que lo oye declamar.

\footnotetext{
${ }^{91}$ Aesop. 2, 123, 2 y 129 Perry, respectivamente.

${ }^{92}$ Aesop. 2, 101 Perry.
} 
Luciano hace mención del vanidoso pájaro en otras obras suyas, en pasajes, donde, de un modo $\mathrm{u}$ otro, subyace siempre la idea de falsedad, de engaño, de hipocresía, referidas a circunstancias diversas, pero predominando en ellas el contexto de la creación literaria o de la práctica oratoria, de manera que pueden ser puestos en paralelo, por su contenido, con el de Pseudologista.

En Icaromenipo, el filósofo de Gádara cuenta a un amigo su increíble experiencia aérea, que le ha llevado a la presencia de Zeus; ante la burla y la incredulidad de su interlocutor, Menipo admite que quizás sus palabras parezcan una fábula, y le explica que, sin embargo, para tan etérea ascensión no necesitó una escalera, ni convertirse en favorito del águila - una alusión al rapto de Ganimedes por parte de Zeus -, pues "tenía mis propias alas"

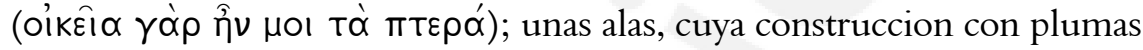
diversas Menipo mismo explicará después, pero que ahora califica de invento digno de Dédalo, ya que el amigo no entiende todavía cómo Menipo pudo transformarse en halcón o en grajo. ${ }^{93}$

Las plumas del grajo son empleadas por Luciano como sinónimo de usurpación - esta vez sin comparación alguna ni referencia explícita al mundo de la fábula -, también en Apología de los que están a sueldo, cuando a través del personaje llamado Sabino, el samosatense se defiende de quienes le reprochan haber aceptado un puesto administrativo en Egipto, a pesar de ser el autor de la obra Sobre los que están a sueldo, donde con dureza describe los inconvenientes de servir en las casas de romanos en tareas educativas. ${ }^{94}$ Éstas son las palabras de Sabino:

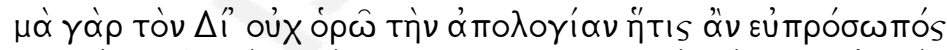

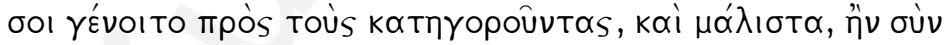

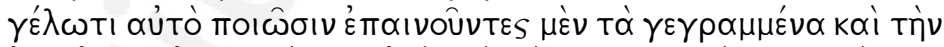

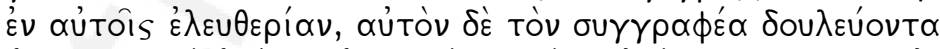

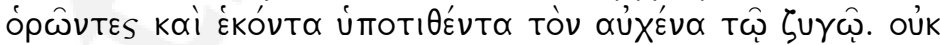

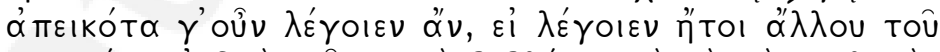

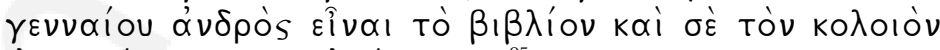

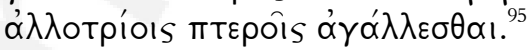

\footnotetext{
${ }^{93}$ Lucianus Icar. 2; Camerotto, op. cit., 2009, p. 98-101.

${ }^{94}$ Cf. Withmarsh, op. cit., p. 248-294.

${ }^{95}$ Lucianus Apol. 4: "No veo, por Zeus, qué clase de defensa podrías tener de buena apariencia ante los que te acusan, y máxime, si con risas alaban tu escrito y la libertad que se expone en él, mientras ven que el escritor se esclaviza y, por voluntad propia, somete su cuello bajo el yugo. No sin razón hablarían, si afirmaran, bien que el libro era de algún otro noble hombre y que tú eres el grajo que se vanagloria con plumas ajenas".
} 
Si el grajo sirve, pues, por su habitual falsedad y presunción, como imagen para describir un supuesto plagio en la producción literaria, todavía en dos ocasiones el samosatense recurre a él para referirse de nuevo a la actividad sofística.

Esto ocurre, de forma indirecta, cuando el zapatero Micilo interroga al gallo - reencarnación, entre otros, de Euforbo, de Pitágoras e incluso de Aspasia - sobre cómo lo pasaba, cuando era un caballo, un pez o una rana, teniendo en cuenta las múltiples y grandes experiencias vividas en sucesivas transmigraciones, en el transcurso de las cuales ha sido también incluso un grajo. ${ }^{96}$ El gallo desprecia la existencia de los ricos y poderosos por sus muchos inconvenientes y, por el contrario, frente a los afanes humanos, elogia la vida natural de los animales, en una argumentación de corte cínico:

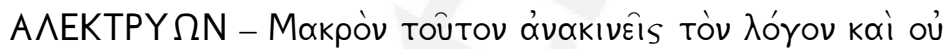

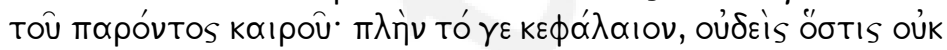

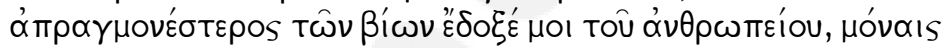

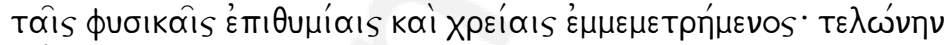

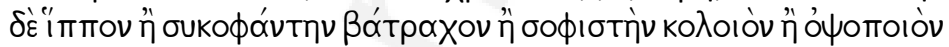

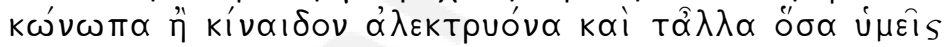

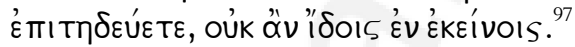

En el preludio Acerca del ámbar o de los cisnes ${ }^{98}$ Luciano defiende su teoría retórica y advierte, como era, al parecer, el objetivo de las $\pi \rho \circ \lambda \alpha \lambda ı \alpha i$, sobre la obra que sigue, y el samosatense, frente a la altisonancia, ampulosidad y fantasia de otros oradores, se propone ofrecer simplemente un relato sencillo, sin mitologías ni canciones, en contraposición al modo de hacer y de actuar de los oradores asianistas. En este preludio se hace referencia al armonioso canto de los cisnes, aves que antes habían sido hombres y cuya voz es sobre todo melodiosa antes de morir. Pero Luciano reflexiona también sobre la poesía, pues, al visitar las tierras lejanas a orillas

\footnotetext{
${ }^{96}$ Lucianus Gall. 20.

${ }^{97}$ Lucianus Gall. 27: Gallo - "Larga es la cuestión que acabas de promover e impropia del momento, pero en resumen te diré que cualquier forma de existencia me pareció siempre más libre de cuidados que la humana, ya que la animal está regida tan sólo por los deseos y necesidades naturales: no verás entre ellos un caballo recaudador de impuestos, una rana delatora, un grajo sofista, un mosquito cocinero, un gallo depravado o cualquier otra práctica habitual entre nosotros".

${ }^{98}$ Schwartz (op. cit., p. 129) considera que esta obra fue compuesta por Luciano en sujuventud.
} 
del Erídano, donde los poetas sitúan los mitos de que él trata ahora, descubre su falsedad: los poetas son unos charlatanes y embaucadores que utilizan los relatos míticos para engañar a sus oyentes. De ahí la perplejidad de unos marineros y su respuesta burlona, cuando el narrador les preguntó cuándo cantan los cisnes:

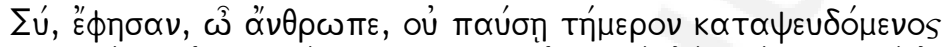

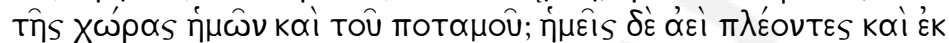

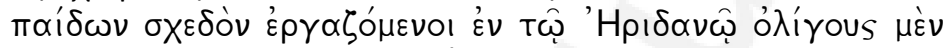

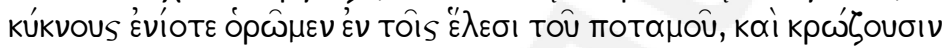

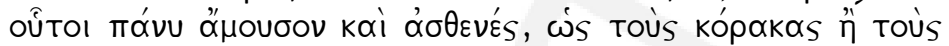

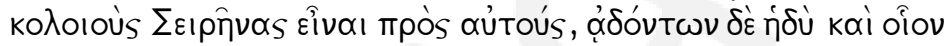

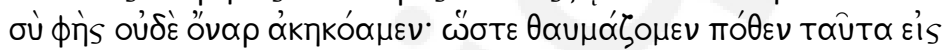

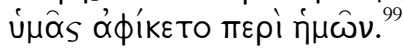

Si los poetas engañan en sus historias, no menos falsedad se encubre en la práctica oratoria contemporánea de Luciano y los rétores son como esos cisnes de los mitos: lejos de cantar con armonía, graznan peor que vulgares grajos, y engañan a los oyentes con facilidad, prometiéndoles en sus declamaciones tesoros de oratoria que son, en realidad, pura vanagloria. ${ }^{100}$

A través de un insignificante pájaro tan falto de belleza como de inteligencia, hemos intentado mostrar cómo Luciano, una vez más, juega con los géneros literarios, transgrediendo de manera natural la forma y el contenido consagrados por la tradición literaria. En su feroz ofensiva verbal contra un crítico falaz, los yambógrafos tomados como ejemplo y modelo de hacer literatura sirven bien a la causa del samosatense, aunque él ahora escriba en prosa. Son poetas que en el arcaísmo griego dejaron de lado la poesía épica y dotaron a la palabra poética de un pragmatismo nuevo al incluir en sus versos yámbicos una nueva realidad, "su" realidad, que, no obstante, bien podía ser igualmente imaginaria, como también ocurre en el caso de Luciano.

En el modo de proceder, en la intención de aquellos poetas y en la de Luciano en Pseudologista destaca un nexo común: la fábula esópica. Un género que, nacido literariamente en la poesía, sigue siendo aun útil por su

\footnotetext{
${ }^{99}$ Lucianus Electr. 5: “¿Es que tú, buen hombre, no dejarás hoy de inventar mentiras sobre nuestro país y el río? Nosotros siempre hemos navegado y trabajamos casi desde niños en el río, y alguna vez hemos visto unos pocos cisnes en las charcas del río, que graznan sin ninguna gracia y sin fuerza, de manera que los cuervos y los grajos son Sirenas a su lado, pero cantar de la forma tan dulce como tú dices, no los hemos oído ni siquiera en sueños. Nos asombra de dónde os han llegado tales fábulas sobre nosotros". ${ }^{100}$ Cf. Karavas, op. cit., p. 161.
} 
validez perenne, en cuanto al contenido, y por su adaptación constante, en cuanto a forma, todavía en la prosa de época imperial, pues, por encima de un uso puramente retórico como recurso para persuadir, ${ }^{101}$ divierte e instruye.

\section{Referencias}

ANDERSON, G. The "pepaideumenos" in action: sophist and their outlook in the early Empire. $A N R W$, Berlin, II 33.1, p. 79-208, 1989.

ANDERSON, G. The Second Sophistic: a cultural phenomenon in the Roman Empire. London: Routledge, 1993.

BOMPAIRE, J. Lucien écrivain: imitation et création. Paris: Les Belles Lettres, 1958.

BRANDÃO, J. L. A poética do Hipocentauro: literatura, sociedade e discurso ficcional em Luciano de Samósata. Belo Horizonte: Editora UFMG, 2001.

BRANHAM, R. B. Unruly Eloquence: Lucian and the comedy of traditions. Cambridge, Mass./ London: Harvard University Press, 1989.

BROWN, C. G. Iambos. In: GERBER, D. E. (org.). A companion to the Greek lyric poets. Leiden: E. J. Brill, 1997, p. 11-88.

CABRERO, M. C. Elogio de la mentira: sobre las "Narraciones Verdaderas" de Luciano de Samósata. Bahía Blanca: EdiUNS, 2006.

CAMEROTTO, A. La metamorfosi della parola: studi sulla parodia in Luciano di Samosata. Pisa-Roma: Istituti Editoriali e Poligrafici Internazionali, 1998.

CAMEROTTO, A. Luciano di Samosata: Icaromenippo o l'uomo sopra le nuvole. Alessandria: Edizioni dell'Orso, 2009.

CASEVITZ, M. La création verbale chez Lucien: Le "Lexiphanes", Lexiphane et Lucien. In: BILLAULT, A. (org.). Lucien de Samosate. Lyon/ Paris: Université Jean Moulin/ de Boccard, 1994, p. 77-86.

CHANTRAINE, P. Dictionnaire étymologique de la langue grecque: histoire des mots. Vol. IV-2. Paris: Klincksieck, 1980.

CRIBIORE, R. Gymnastics of the mind: Greek education in Hellenistic and Roman Egypt. Princeton: Princeton University Press, 2001.

DEGANI, E. Note sulla fortuna di Archiloco e di Ipponatte in epoca ellenistica. QUCC, Pisa, vol. 16, p. 79-104, 1973.

DIJK, G.-J.van. The fables in the Greek "Life of Aesop”. Reinardus, Zürich, vol. 8, p. 131-150, 1995.

${ }^{101}$ Arist. Rh. II 20, 1393 a 30. 


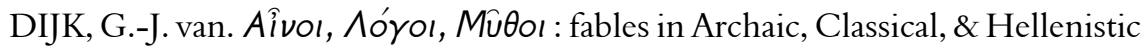
Greek literature. Leiden/ New York/ Köln: E.J. Brill, 1997.

FERNÁNDEZ DELGADO, J. A. Influencia literaria de los "progymnasmata". In: FERNÁNDEZ DELGADO, J. A.; PORDOMINGO, F.; STRAMAGLIA, A. (org.). Escuela y literatura en Grecia antigua. Cassino: Università degli Studi di Cassino, 2007, p. 273-306.

GEORGIADOU, A.; LARMOUR, D. H.J.Lucian's science fiction novel "True Histories”: interpretation \& commentary. Leiden/ Boston/ Köln: E.J. Brill, 1998.

GÓMEZ, P. La "Vida d'Isop" entre el iambe, la faula i la novella. Barcelona: Universitat de Barcelona. Departament de Filologia Grega, 1987. < http://hdl.handle.net/10803/ 1694> [Consulta: 19 marzo 2013].

GÓMEZ, P. De la iniciación poética de Esopo. In: Actas del VII Congreso español de estudios clásicos. Vol. II. Madrid: Editorial de la Universidad complutense, 1989, p. 217-223.

GÓMEZ, P. El frigi del mimiamb V d'Herodes. Ítaca, Barcelona, vol. 6-8, p. 71-80, 1990-1992.

GÓMEZ, P. Los animales también ríen. In: ALVAR, A.; GARCÍA JURADO, F. (org.). Actas del X Congreso Español de Estudios Clásicos. Vol. I. Madrid: Sociedad Española de Estudios Clásicos/Ediciones Clásicas, 2000, p. 431-438.

GÓMEZ, P. Fábulas en la edad tardía: Esopo y el helenismo. In: PÉREZ JIMÉNEZ, A.; CRUZ ANDREOTTI, G. (org.). "Así dijo la zorra": la tradición fabulística en los pueblos del Mediterráneo. Madrid/ Málaga: Ediciones Clásicas/ Charta Antiqua, 2002, p. 49-87.

GÓMEZ, P. Cynicism and Hellenism in the "Letters" of Anacharsis and the Vita Aesopi.Lexis, Venecia, vol.21, p. 319-332, 2003 a.

GÓMEZ, P. Sofistas, según Luciano. In: NIETO, J. M. (org.). LÓGOS HELLENIKÓS: homenaje al profesor Gaspar Morocho Gayo. Vol. I. León: Universidad de León, 2003b, p. 277-284.

GÓMEZ, P.El "Maestro de oradores" de Luciano: ¿̇retrato de un sofista? In: ALVAR, A.; GONZÁLEZ, F. J. (org.). Actas del XI Congreso de la Sociedad Española de Estudios Clásicos. Vol. I. Madrid: Sociedad Española de Estudios Clásicos, 2005, p. 329-339.

GÓMEZ, P. Paideia nutricia: las artes del saber y del comer en Luciano. CFC (g), Madrid, vol. 21, p. 247-260, 2011.

GÓMEZ, P.; VINTRÓ, E. Gastronomic philosophy, or the "pepaideumenos" as parasite. In: ÇEVIK, M. (org.). International Symposium on Lucianus of Samosata. Adiyaman: Adiyaman University, 2008, p. 191-206.

GÓMEZ, P.; JUFRESA, M. Llucià a taula: aliments i simposi. In: MESTRE, F.; GÓMEZ, P. (org.). Lucian of Samosata: Greek writer and Roman citizen. Barcelona: Publicacions i Edicions de la Universitat de Barcelona, 2010, p. 99-113.

HALL, J.Lucian's satire. New York: Arno Press, 1981. 
HOLZBERG, N. (org.). Der Äsop-Roman: Motivgeschichte und Erzählstruktur. Tübingen: Gunter Narr, 1992.

HOLZBERG, N. Novel-like works of extended prose fiction II. In: SCHMELING, G. (org.). The novel in the ancient world. Leiden/New York/Köln: E.J. Brill, 1996, p. 619-653.

JEDRKIEWICZ, S. Sapere e paradosso nell'Antichità: Esopo e la favola. Roma: Edizioni dell'Ateneo, 1989.

JEDRKIEWICZ, S. Il convitato sullo sgabello: Plutarco, Esopo ed i Sette Savi. Pisa/ Roma: Istituti editoriali e poligrafici internazionali, 1997.

JEDRKIEWICZ, S. Animales y "sophía": la fábula esópica como saber universal. In: PÉREZ JIMÉNEZ, A.; CRUZ ANDREOTTI, G. (org.). "Así dijo la zorra”: la tradición fabulística en los pueblos del Mediterráneo. Madrid/ Málaga: Ediciones Clásicas/Charta Antiqua, 2002, p. 19-48.

JOUANNO, C. Vie d'Ésope. Livre du Philosophos Xanthos et de son esclave Ésope. Du mode de vie d'Ésope. Paris: Les Belles Lettres, 2006.

KARAVAS, O. El orador-cisne: Luciano, la retórica y los rétores. CFC (g), Madrid, vol. 16, p. 157-164, 2006.

KENNEDY, G. A. A new history of classical rhetoric. Princeton: Princeton University Press, 1994.

MESTRE, F. Filóstrato y los "progymnasmata”. In: FERNÁNDEZ DELGADO, J. A.; PORDOMINGO, F.; STRAMAGLIA, A. (org.). Escuela y literatura en Grecia antigua. Cassino: Università degli Studi di Cassino, 2007, p. 523-556.

MESTRE, F. Declamation by Deceit: a Sophist's Trickery. In: MARTÍNEZ, J. (org.). Mundus vult decipi. Estudios interdisciplinares sobre falsificación textual y literaria. Madrid: Ediciones Clásicas, 2012, p. 263-273.

MESTRE, F.; GÓMEZ, P. Les sophistes de Philostrate. In: LORAUX, N.; MIRALLES, C. (org.). Figures de l'intellectuel en Grèce ancienne. Paris: Belin, 1998, p.333-369.

MESTRE, F.; GÓMEZ, P. Retórica, comedia, diálogo: la fusión de géneros en la literatura griega del s. II d.C. Myrtia, Murcia, vol. 16, p. 11-122, 2001.

MESTRE F.; GÓMEZ, P.; VINTRÓ, E. Helena se cubre el rostro en la Isla de los Bienaventurados (Lucianus, VH 2.26). In: DE LA VILLA, J.; GONZÁLEZ, J. F.; HINOJO, G. (org.). Perfiles de Grecia y Roma. Vol. II. Madrid: Sociedad Española de Estudios Clásicos, 2010, p. 573-579.

MIRALLES, C.; PÒRTULAS, J. Archilochus and the Iambic Poetry. Roma: Edizioni dell'Ateneo, 1983.

MORGAN, T. Literate education in the Hellenistic and Roman worlds. Cambridge: Cambridge University Press, 1998.

MORGAN, T. Popular morality in the early Roman Empire. Cambridge: Cambridge University Press, 2007.

MORAUX, P. Diogène Laërce et le "Péripatos”. Elenchos 7, Napoli, p. 245-294, 1986. 
MONTANARI, F. L'erudizione, la filologia e la grammatica. In: CAMBIANO, G.; CANFORA, G.; LANZA, D. (org.). Lo spazio letterario della Grecia antica. Vol. I tom. II (l'Ellenismo). Roma: Salerno Editrice, 1993, p. 235-281.

NØJGAARD, M. La fable antique, I: La fable grecque avant Phèdre. Copenhague: Nyt Nordisk Forlag, 1964.

PERRY, B. E. Aesopica. Urbana: The University of Illinois Press, 1952.

REARDON, B. P. Courants littéraires grecs des IIè et IIIè siècles aprèsJ.-C. Paris: Les Belles Lettres, 1971.

RODRÍGUEZ ADRADOS, F. La tradición fabulística griega y sus modelos métricos. Emerita, Madrid, vol. 38, p. 1-52, 1970.

RODRÍGUEZ ADRADOS, F. Prolegómenos al estudio de la fábula en época helenística. Emerita, Madrid, vol. 46, p. 1-81, 1978.

RODRÍGUEZ ADRADOS, F. Historia de la fábula greco-latina. Madrid: Editorial de la Universidad Complutense, 1979a.

RODRÍGUEZ ADRADOS, F. The "Life of Aesop" and the origins of the novel in Antiquity. QUCC, Pisa, vol. 30, p. 93-112, 1979b.

RODRÍGUEZ ADRADOS, F. La fecha de la Augustana y la tradición fabulística antigua y bizantina. Prometheus, Firenze, vol. 18, p. 139-149, 1992.

RUÍZ MONTERO, C. La novela griega: panorama general. Cuadernos de literatura griega y latina, Santiago de Compostela, vol. V, p. 313-342, 2005.

RUÍZ MONTERO, C.; SÁNCHEZ, M. D. La estructura de la "Vida de Esopo": análisis funcional. Habis, Sevilla, vol. 36, p. 243-252, 2005.

SCHWARTZ, J. Biographie de Lucien de Samosate. Bruxelles: Latomus. Revue d'études latines, 1965.

WEBB, R. The "Progymnasmata" as practice. In: TOO, Y. L. (org.). Education in Greek and Roman Antiquity. Leiden: E.J. Brill, 2001, p. 289-316.

WHITMARSH, T. Greek literature and the Roman Empire: the politics of imitation. Oxford: Oxford University Press, 2001. 